\title{
Interplay between Beliefs about Reading Stratagems and Classroom Practices of Secondary School Teachers in Teaching Reading Comprehension
}

\author{
* Itbar Khan (Corresponding Author) \\ ** Farooq Nawaz Khan \\ *** Nazia Saeed
}

\begin{abstract}
The current study is built on the idea that teachers' classroom practices are influenced by their belief system. The research investigated the beliefs of teachers about the position of reading stratagems, and their classroom implementation among 141 secondary school English teachers and found the association between their beliefs about the position of reading comprehension stratagems and their classroom application. It is a descriptive study, data were collected through a questionnaire. Means and Pearson correlation were calculated for finding out the relationship between the variables. The study found that reading stratagems in reading comprehension and their practices in classrooms are positively correlated. The study recommends understanding the conceptions of English language teachers in schools for the effective teaching of English in general and reading stratagems in particular.
\end{abstract}

Keywords: Teachers' Beliefs, Reading Strategies, Classroom Practices, Teaching of Reading in Pakistan

\section{Introduction}

Teachers are considered as the most important individuals of the community; they facilitate their pupils to take responsibilities on their shoulders and to develop their nation (Drukpa, 2010). Many factors have an important bearing on the practices of teachers. According to Ibrahim and Amani (2014), beliefs are important in the lives of all human beings, and the teachers' teaching practices are also influenced by certain beliefs of teachers. According to Calderhead (1996) teachers have clearly and readily seen beliefs. Beliefs about teaching reading are no exceptions.

English is included in the curriculum as a foreign language in Pakistan from K1-12 as a compulsory subject. The core resolve of instruction in English is to assist students to converse in English and improve skills in English to understand other academic subjects. These days all curricula from grade1 till tertiary education are offered in English and this has increased the importance of English

All skills of the English language are considered important but reading is the most important skill; without these skills, learners cannot benefit from other subjects. Reading is considered the most important skill not only in English but in every language. It offers knowledge and expressions and compositions for language learners (Carrell, 1984). Goodman (1995) called reading is the receptive part of communication". Grabe (1991) called reading a dynamic process of comprehension. Reading skills and their uses are needed for effective reading (Garner, 1987)

English language teachers can become effective teachers when they teach language strategies to the students and use strategies for teaching reading skills. Strategies enable the learners to monitor their learning and become independent learners of language (Lessard-Clouston, 1997). Teachers have their perceptions or beliefs about teaching reading strategies. And the practices of teachers are affected by their beliefs (Johnson, 1992, Woods, 1996). Fatemeh and Salimi (2010) established that reading stratagems play a vital role in understanding a text. The study also found a miss-match

\footnotetext{
* Faculty of Education, University of Malakand Email: educationmkd@ gmail.com

** Center for Education and Staff Training, University of Swat Email: farooqlit76@gmail.com

*** Faculty of Education, University of Malakand Email: ilivm111@gmail.com
} 
between beliefs and classroom practices. Language teachers need to teach reading stratagems to students for effective understanding of reading items (Lessard-Clouston, 1997:3)

It is essential to investigate the beliefs of teachers because many studies have found a positive correlation between beliefs and classroom practices. Moreover, when teachers know their beliefs they would change their practices over time Gilakjani and Sabouri, (2017). Education policy 2006, emphasizes upon reading skills of students, and USAID Reading Project Pakistan is also working these days in Pakistan on the reading skills of Teachers. But the beliefs about reading stratagems and their effect on classroom practices are least investigated in Pakistan. To make the teachers more efficient in their performance there is essential to explore the beliefs of teachers regarding classroom practices and the teaching of reading stratagems. And it is essential to investigate because it would change their teaching methods in the long run.

\section{Problem Statement}

Research has shown that there is an association between beliefs and classroom practices of teachers. The current research investigated the beliefs of secondary school teachers about the importance of reading stratagems and found the relationship of beliefs with classroom practices of secondary school teachers in Khyber Pakhtunkhwa.

\section{Objectives}

The objectives of the study were to:

1. identify the conceptions of secondary school teachers about the importance of reading stratagems in reading comprehension;

2. examine the actual classroom behaviors in the application of reading stratagems for reading comprehension at the secondary level, and

3. find out the association between teachers' beliefs reading stratagems and their classroom implementation in the teaching of reading comprehension at secondary schools.

\section{Literature Review}

Teachers have their perceptions about students, learning, teaching, curriculum, learning to teach, and beliefs about themselves Calderhead, 1996). Nespor (1987) believes that the beliefs of teachers are more important than the knowledge which they possess because the former exert greater influence than the knowledge. Teachers are likely to teach the way, they believe. The beliefs of people are lying beyond the control of individuals. Richardson \& Anders (1991) found that beliefs are correlated positively to classroom practices.

There are certain strategies for teaching English, some of them are more important than others, for instance predicting the meaning of the unclear words, elucidating vocabulary difficult words, scanning the reading material, and translating into Arabic was the least used strategy (Ebrahim, M. Bamanger, and Amani, K. Gashan (2014). Mehr, Rouhani, Abolfath, Ali, S. K., and Arzoo (2015) found that English language teachers preferred cognitive strategy, metacognitive knowledge, and linguistic knowledge.

Many studies found consistency in the conceptions and their classroom behavior. For example. There is a connection between teachers' conceptions about teaching and their classroom behavior. They found that teachers' beliefs were changed by their learning practices during their student lives Johnson (1994). Wang (2006) surveyed 14 classrooms in China and found consistency in the conceptions and classroom behaviors. Zheng and Borg (2013) researched the beliefs of the practical employment of the task-based learning of English of 3 secondary school teachers' in their classes. They found teachers practically applied and interpreted the rules of task-based learning according to their beliefs.

On the other hand, many studies have shown inconsistency in conception about teaching classroom behaviors of teachers. As Al- Abdul Kareem (2004) found science teachers believed in inquiry teaching but their classroom practices did not support their conceptions. Similarly, Bisland B, O'Connor E, and Malow-Iroff, M. (2009) found a contradiction in beliefs and practices of social science teachers in New York. Shun (2008) looked at the relationship between teachers' conceptions and practices, and he found that teachers used the traditional methods, although they believed in other approaches. Similarly, Khomri and Salim (2010) found no positive correlation between conceptions and practices. 


\section{Models of Reading}

Reading is an important activity in academic life as well as non-academic life. Book is considered the best friend when no one is ready to accompany you. There are various models of teaching and learning reading. Three of them, bottom-up, bottom down and interactive models are the major models. In the bottom-up model, the readers develop meanings from letters, words, phrases, and sentences. The reader understands them and takes meaning from them (Yorio, 1971). In the top-down model, the reader comes first. He brings his background knowledge of the topic and interact with the whole text (Smith, 1994). As according to Anderson (1996: 1) reading means an active process wherein the reader and the text interact and gets meanings. The interactive model emphasizes the active role of background knowledge and the speedy processing of letters, words, and sentences. Meanings from the text are determined based on information obtained from the two sources: text and reader (Hayes, 1997).

\section{Reading Strategies}

Reading strategies are defined as specific actions taken for enhancing reading skills (Oxford, 1992). O'Malley and Chamot (1990) has given the following strategies which are necessary for readers 1) previewing the main idea, skimming (taking the general idea, scanning (picking specific information), monitoring for comprehension, evaluation, making use of resources, like a dictionary, textbooks, deduction, imagery, inferencing, guessing, summarizing, main idea of a lesson and translating foreign language into the mother tongue. As per Brantmeier (2002) skimming, checking, speculating, perceiving cognates and word families, perusing for significance, anticipating, enacting general information, making deductions, following references, and isolating primary thoughts from supporting thoughts. Dark-colored (1990) offered seeing implications from titles, headings, anticipating, skimming, checking, speculating, and rewording as systems for perusing.

\section{Methodology of the Study}

The study used a correlational study design to find out the connection between beliefs of English teachers about the position of reading stratagems, and their implementation in secondary schools in Khyber Pakhtunkhwa (KP), Pakistan.

\section{Population and Sample}

There are 108 high and higher schools in Dir Lower where about 200 English teachers teach English in these schools. Primary data were collected from 141 teachers who were randomly selected from the whole population. All the randomly selected teachers were male, and they had been teaching English subject for many years. Their experiences were about 4 to 24 years. All the teachers have a master or bachelor degrees in one or other subjects along with professional qualification, bachelor or master degrees in education.

\section{Data Collection Instrument}

The study used a questionnaire for understanding conceptions of teachers about reading stratagems and implementation in the classroom developed by Chou (2008) with necessary changes according to the culture and level of teachers. The questionnaire has 3 parts but this study used only 2 parts - the importance of reading strategies and actual enactment. There are 20 items in each part. The questionnaire uses a 5 point Likert Scale. The Cronbach alpha was .80 and .76 for sections respectively. This is considered an appropriate level. The questionnaire was pilot tested on 30 teachers to see the reliability of the questionnaire. There were technical words that all teachers did not know without explanation. They were changed into common words. Those technical words were defined for clear understanding. The questionnaire was also validated by 4 persons who are experts in the field. The researchers distributed 180 questionnaires among the teachers, some of the teachers did not respond. At the end of data collection, the researchers got a 141 filled questionnaire, 5 forms were rejected because teachers had not filled them.

\section{Data Analysis}

Table 1

Conceptions about the Position of Reading Stratagems

\begin{tabular}{lll}
\hline Statement & Mean & SD \\
\hline 1. teaching difficult words & 3.78 & 1.36 \\
2. Mechanics of language & 3.78 & 1.24 \\
3. loud reading & 3.27 & 1.09 \\
4. Explaining the content in Urdu & 3.35 & 1.23
\end{tabular}


5. Foundation learning about the topic

6 . Finding the association of each section

7. Types of content

8. Questions about heading

9. Speculating the significance of words

10. Search for particular words

11. Birds eye view of meaning

12. Discovering primary thought

13. Brief of the topic

14. Sketching the lesson

15. Recapping the text

16. Anticipating meanings

17. Checking perusing continuously

18. Inquiring for check understanding

19. Using word references

20. Using visual help

$\begin{array}{ll}3.27 & 1.14 \\ 3.2 & 1.23 \\ 3.08 & 1.15 \\ 3.43 & 1.22 \\ 3.26 & 1.22 \\ 3.01 & 1.21 \\ 3.1 & 1.05 \\ 3.43 & 1.12 \\ 3.4 & 1.08 \\ 3.04 & 1.21 \\ 3.12 & 1.12 \\ 3.41 & 0.97 \\ 3.4 & 1.11 \\ 1.17 & 1.17 \\ 3.36 & 1.15 \\ 3.08 & 1.26\end{array}$

1.14

1.23

1.22

1.22

1.21

1.12

1.08

1.21

1.12

1.11

1.17

1.26

Table1 shows the beliefs of teachers about reading strategies. According to the teachers the two most important teaching strategies were teaching of vocabulary and grammar while the next emphasis was laid on the main idea and title. Monitoring reading comprehension and summarizing followed. Translating into Urdu as strategy fell at number 5.

Table 2

Use of Reading Stratagems in Teaching Practices

\begin{tabular}{lll}
\hline Statement & M & SD \\
\hline 1. Difficult words & 3.78 & 1.36 \\
2. Instructions about punctuation & 3.65 & 1.24 \\
3. Resounding the content & 3.27 & 1.09 \\
4. Explaining the content in Urdu & 3.35 & 1.23 \\
5. Foundation learning about the topic & 3.27 & 1.14 \\
6. Linking different sections of the topics & 3.2 & 1.12 \\
7. Types of content & 3.08 & 1.15 \\
8. Identifying title & 3.43 & 1.17 \\
9. ways of figuring out the meanings of words & 3.26 & 1.22 \\
10. ways of Checking data & 3.01 & 1.21 \\
11. ways of getting the general idea of the text & 3.1 & 1.04 \\
12. Explain the basic theme of a lesson & 3.4 & 1.1 \\
13. How to make brief of a lesson & 3.4 & 1.08 \\
14. How to do plotting of a lesson & 3.0 & 1.21 \\
15. Retelling activities & 3.12 & 1.12 \\
16. Inquiring about theme & 3.41 & 0.97 \\
17. Questions about the perceptions of learners & 3.36 & 1.17 \\
18. Inquiries to check perceptions & 3.36 & 1.17 \\
19. How to utilize word references & 3.36 & 1.15 \\
20. activities for taking help from visuals & 3.08 & 1.26 \\
\hline
\end{tabular}

Table 2 shows data about the necessity of reading strategies. The two most important teaching theories suggested by the higher secondary schools teachers were teaching of vocabulary and grammar while the rest were ordered as follows: identifying title, teaching students how to find the main idea, summarizing, monitoring comprehension, asking comprehension questions, how to use a dictionary and translating into Urdu.

Table 3

Correlation between beliefs and practices

\begin{tabular}{lccc}
\hline Variables & $\mathrm{N}$ & Correlation & significance \\
\hline $\begin{array}{l}\text { Beliefs about reading theories } \\
\text { Classroom behaviors }\end{array}$ & 140 & $.641^{* *}$ & .000 \\
\hline
\end{tabular}

**. Correlation is significant at the 0.01 level (2-tailed).

Table 3 shows that there was a significant association between the beliefs about teaching reading comprehension of teachers and their actual teaching reading comprehension strategies in the classroom. 


\section{Results}

1. Data showed that the teachers ranked the strategies according to their importance as under: 1) vocabulary teaching, 2) grammar teaching, 3) translating into Urdu 4) Using dictionaries. These are the most common strategies which teachers believe to be useful for learning English.

2. The teachers ranked the actual use of strategies in the classroom as under: First, teaching Vocabulary, second, asking for the main idea, third, translating into Urdu, use of the dictionary, fourth and translating into Urdu, and so on. It is clear that contextualizing, guessing meaning and searching connections are the least practiced behaviors in teaching reading.

3. It was found that there was a significant positive correlation among the beliefs of teachers about reading strategies and the actual teaching of teachers in classrooms.

\section{Discussion}

The results of this study extend the findings of Ebrahim and Amani (2014) who examined the beliefs of teachers about the import of teaching English reading stratagems and found the influence of beliefs on their classroom teaching practice. The teachers gave the first emphasis on guessing meaning, second, explain vocabulary items, third, asking questions for comprehension where translation into Arabic was considered as the least important. They found a significant association between beliefs and practices. In our study, the teachers placed translation in the fourth position. It shows that our teachers still like and uses the grammar-translation method. Our study also corroborates the findings of Chou (2008; Molly (2009); Harcarik (2009); Kuzborska (2011); Mohamed (2006), Grabe, (1991), (Allan \&Bruton, 1998); Fatemeh \& Salimi (2010), Richardson \& Anders (1991); Alabdulkareem, (2004); Phillips (2009), Khan, I. (2018).

The findings of our research are contrary to the findings of Basturkmen, Loewen, and Ellis (2004). Findings who found an inconsistent association among the beliefs teachers and their actual instructional practice. Similarly, Khonamri and Salim (2010) found that the beliefs of teachers do not reflect classroom teaching practices. However, most of the research in this area showed consistency with the present study. Johnson (1992) research showed that there was a significant relationship between English as second language teachers' beliefs and their teaching practices. Smith (1996) found that the option of teaching approaches, learning tasks, and curriculum design are significantly influenced by the beliefs. Similarly, Chou's (2008) results showed consistency of the relationship among beliefs of teachers' and their actions in classrooms. The conclusion of the research of Kuzborska (2011) about what teachers believe and their approaches to teaching they employ in their method of teaching the English language showed a positive correlation. Our findings also extend the findings of Mehr, Ali, and Omidvari (2015) studied the conceptions of English language teachers high school reading strategies and their influence on practices using Chuo (2008) on reasoning, thinking stratagems, and linguistic understanding. They also established strong proof that theories, strategies, and classroom behaviors are connected and they have influenced classroom implementation activities of teachers.

\section{Conclusions}

1. It is concluded based on the above findings that secondary school teachers have their own beliefs about reading strategies. They preferred teaching vocabulary and grammar. They also translate English into Urdu. All these are very traditional ways of teaching English which is still practiced in most of the Pakistani schools.

2. There is the least use of background knowledge, asking questions about titles, guessing meanings, and direct method of teaching. There is a significant correlation between the beliefs and classroom practices of teachers. It shows, like many other studies, that beliefs have a relationship with the behavior or practice of teachers. Beliefs of teachers are harbingers of what they will do in the field. Therefore, it is necessary to work on the beliefs of teachers when there is a professional development program, curriculum implementation, or any innovation in the field of education.

3. It is concluded based on the above findings that secondary English language teachers have their beliefs about reading strategies. They preferred teaching vocabulary and grammar. They 
also translate English into Urdu. All these are very traditional ways of teaching English which is still practiced in most of the Pakistani schools.

4. There is a rare use of background knowledge and a direct method of teaching. There is a significant correlation between the beliefs and classroom practices of teachers. It shows, like many other studies, that beliefs have a relationship with the behavior or practice of teachers. Beliefs of teachers are harbingers of what they will do in the field. Therefore, it is necessary to work on the beliefs of teachers when there is a professional development program, curriculum implementation, or any innovation in the field of education.

\section{Suggestions and Recommendations}

1. It is recommended based on the above conclusions that English teachers need to consider research-based approaches towards the teaching of reading.

2. Teacher trainers may discuss about beliefs of teachers before giving any training to the teachers about strategies of reading.

3. Curriculum developers may also consider the beliefs of teachers about the teaching of English. Moreover, teacher education courses should also have content about the beliefs of teachers.

\section{References}

Al-Abdulkareem, S. (2004).Investigating Science Teachers Beliefs about Science and Science teaching. Struggles in Implementing Science Education, Reform in Saudi Arabia, Ph.D. theses Submitted to West Virginia University.

Al-Abdulkareem, S. A. (2004). Investigating science teachers' beliefs about science and science teaching: Struggles in implementing science education reform in Saudi Arabia. Unpublished doctoral dissertation. West Virginia University. Morgantown, WV.

Allan, J., \& Bruton, A. (1998).Squeezing out the Juice: Perceptions of reading in the secondary school. Edinburgh: Scottish Council for Research in Education.

Anderson, N.J (1999). Exploring Second Language Reading: Issues and Strategies. Toronto: Heinle \& Heinle Publisher

Anderson, R. C. (1996). Research foundations to support wide reading. Promoting reading in developing countries, 55-77.

Basturkmen, H., Loewen, S., \& Ellis, R. (2004). Teachers' stated beliefs about incidental focus on form and their classroom practices. Applied linguistics, 25(2), 243-272.

Bisland B, O'Connor E, and Malow-Iroff, M. (2009).Beliefs and Issues in Social Studies Instructional Practices: A Case Study of Alternatively Certified Elementary Teachers. Paper presented at the College and University Faculty Assembly of the National Council for the Social Studies, Atlanta, GA.

Brantmeier, C. (2002). Second language reading strategy research at the secondary and university levels: Variations, disparities, and generalizability. The Reading Matrix, 2(3).

Calderhead, J. (1996). Teachers: Beliefs and knowledge.

Carrell, P. Devine, J and Eskey, D. (1984). Interactive Approaches to Second Language Reading. Cambridge: Cambridge University Press.)

Chou, Y.C. (2008). Exploring the Reflection of Teachers' Beliefs about Reading Theories and Strategies on Their Classroom Practices. Feng Chia Journal of Humanities and Social Sciences, 16,183-216.

Drukpa, S. (2010). Job Satisfaction of Secondary School Teachers in Thimphu District of Bhutan. M.Ed. Thesis.

Ebrahim M. Bamanger1\&Amani K. Gashan (2014). In-Service EFL Teachers' Beliefs about Teaching Reading Strategies. Canadian Center of Science and Education English Language Teaching, 7(8).

Garner, R. (1987). Metacognition and reading comprehension. Norwood, NJ: Ablex

Gatbonton, E. (1999). Investigating experienced ESL teachers' pedagogical knowledge. Modern Language Journal, 83(1), 35-50.

Gilakjani, A. P., \& Sabouri, N. B. (2017). Teachers' Beliefs in English Language Teaching and Learning: A Review of the Literature. English Language Teaching, 10(4), 78-86.

Goodman, Y. M. (1995). Miscue Analysis for Classroom Teachers: Some History and Some Procedures. Primary Voices K-6, 3(4), 2-9.

Grabe, W. (1991).Current developments in second language reading research. TESOL Quarterly, 25(3), 375-406. http://dx.doi.org/10.2307/3586977 
Harcarik, M. (2009). Fifth-Grade Teachers' Social Studies Knowledge and Beliefs and their Relationship to Classroom Practices. Unpublished Doctoral Thesis. The University of Florida, USA.

Hayes, M., \& Jenkins, J. (1991). Reading instruction in special education resource rooms. American Educational Research Journal 23, 161-190.

Johnson, K. E. (1990). The theoretical orientations of English as a second language teachers: The relationship between beliefs and practices. Journal of Reading Behavior, 24, 83-108.

Johnson, K. E. (1992). The relationship between teachers' beliefs and practices during literacy instruction for non-native speakers of English. Journal of Reading Behavior, 24(1), 83-108.

Johnson, K. E. (1994). The emerging beliefs and instructional practices of pre-service English as a second language teachers. Teaching and Teacher Education, 10(4), 439-452. http://dx.doi.org/10.1016/0742-051X (94)90024-8

Khan, I. (2018). Relationship of teacher educators epistemological beliefs and instructional beliefs with instructional practices: An analytical study [Doctoral Dissertation, International Islamic University Islamabad]. Pakistan Research Repository: http://prr.hec.gov.pk/jspui/

Konami, F., \& Salimi, M. (2010). The Interplay between EFL High School Teachers' beliefs and their Instructional Practices Regarding Reading Strategies. Novitas-Royal, 4(1)

Khonamri, F., \&Salim, M. (2010).The interplay between EFL high school teachers' beliefs and their instructional practice regarding reading strategies. Novitas-ROYAL (Research on Youth and Language), 4(1), 96-107.

Kuzborska, I. (2011). Links between teachers' beliefs and practices and research on reading. Reading in a Foreign Language, 23(1), 103-129. Retrieved from http://search.ebscohost.com/login. aspx ?direct=true $\& \mathrm{db}=$ ehh $\& \mathrm{AN}=66913387 \&$ site $=$ eds-live

Lessard-Clouston, M. (1997). Language learning strategies: An overview of L2 teachers. The Internet TESL Journal, 3(12), 69-80.

Mariea, D., Stoube, F. (2009). The emergence and development of preservice teachers' professional belief systems about reading and reading instruction. Ph.D. (Doctor of Philosophy) thesis, University of Iowa,

Mehr, Rouhani, Abolfath, Seyyed Kazemi Ali, and Arzoo. (2015).The Effect of Teachers' Beliefs on their Instructional Practices: Regarding Teaching Reading Strategies. Indian Journal of Fundamental and Applied Sciences 5: 3614-3631. Accessed March 24, 2016. www.citbtech.org/sp.ed.

Ministry of Education (2006). National curriculum for English, grade IV-VIII. Islamabad: Government of Pakistan

Mohamed, N. (2006).An exploratory study of the interplay between the teachers' beliefs, instructional practices, and professional development. Doctor of Philosophy in Language Teaching and Learning, the University of Auckland 250-570.

Nespor, J. (1987). The role of beliefs in the practice of teaching. Journal of curriculum studies, 19(4), 317328.

Nespor, J. (1987).The role of beliefs in the practice of teaching. Journal of Curriculum Studies, 19(4), 317328.

O'malley, J. M., O'Malley, M. J., \& Chamot, A. U. (1990). Learning strategies in second language acquisition. Cambridge university press.

Oxford, R.L. (1990). Language Learning Strategies: What Every teacher should know. New York: Newbury House.

Richardson, V., Anders, P., Tidwell, D., \& Lloyd, C. (1991). The relationship between teachers' beliefs and practices in reading comprehension instruction. American educational research journal, 28(3), 559-586.

Shun, L. (2008). Teacher Beliefs and their implications for enhancing instructional practices. Center for Research in Pedagogy and Practice, Singapore.

Wang, W. (2006).Exploring teacher beliefs and practices in the implementation of a new English language curriculum in China: Case studies. APERA conference. University of Hong Kong.

Yorio, C. A (1971). Some sources of reading problems for foreign language learners. Language Learning $21(1) 107-115$.

Zheng, X., \& Borg, S. (2013). Task-based learning and teaching in China: Secondary school teachers' beliefs and practices. Language Teaching Research. 